\title{
Marriage Mobility and Footbinding in Pre-1949 Rural China: A Reconsideration of Gender, Economics, and Meaning in Social Causation
}

\author{
MELISSA J. BROWN, LAUREL BOSSEN, \\ HILL GATES, AND \\ DAMIAN SATTERTHWAITE-PHILLIPS*
}

\begin{abstract}
We provide evidence contrary to long-standing general expectations that before 1949 most Chinese women married up the social hierarchy and that footbinding facilitated this hypergamy. In our sample of 7,314 rural women living in Sichuan, Northern, Central, and Southwestern China in the first half of the twentieth century, two-thirds of women did not marry up. In fact, 22 percent of all women, across regions, married down. In most regions, more women married up than down, but in all regions, the majority did not marry hypergamously. Moreover, for most regions, we found no statistically significant difference between the chances of a footbound girl versus a not-bound girl in marrying into a wealthier household, despite a common cultural belief that footbinding would improve girls' marital prospects. We do find regional variation: Sichuan showed a significant relation between footbinding and marital mobility. Nevertheless, our evidence of the basic economic circumstances of rural women's marriages from several of China's regions, including Sichuan, supports a different cultural belief as relevant to the lives of most women: marriage among equals. These results have implications for understanding pre-1949 Chinese gender relations and rural life as well as for theorizing social causation.
\end{abstract}

$\mathrm{I}^{\mathrm{T}}$ HAS LONG BEEN assumed that before 1949 Chinese society was hypergamous - that most women married to a "better" household than the one in which they were born (Blake 1994, 702; Ebrey 1991, 5). The 15 to 20 percent "surplus" of males (beyond the number of women in the population) that

\footnotetext{
Melissa J. Brown (mjbrown@umn.edu) is Senior Research Associate at the Minnesota Population Center, University of Minnesota-Twin Cities, and Visiting Scholar at the Fairbank Center for Chinese Studies, Harvard University. Laurel Bossen is Professor Emerita at McGill University. Hill Gates is Professor Emerita at Central Michigan University. Damian Satterthwaite-Phillips is Postdoctoral Fellow at the Illinois Natural History Survey, University of Illinois at Urbana-Champaign.

*Author contributions: MJB collected data for Hubei, Hunan, Jiangxi, Yunnan, and Guizhou; conducted analysis; wrote the paper; and is responsible for its contents. LB collected data for Shaanxi, Henan, Anhui, and Yunnan and contributed analytic and textual feedback. HG collected data for Sichuan, Shanxi, Hebei, and Shandong and contributed analytic and textual feedback. DS-P performed the statistical analyses and contributed analytic feedback.
} 
characterized late Qing and early twentieth-century Chinese demographics (Sommer 2000, 13; Telford 1992) should have assured women of upward mobility in marriage. Further, mothers often justified the pain of footbinding, which was by no means limited to the well-to-do, to little girls as a means to marriage. ${ }^{1}$ Expectations, then, from the marriage market and rural women's beliefs about the meaning of footbinding suggest that hypergamy was an important part of rural Chinese life and footbinding contributed to it. Evidence given here shows that two-thirds of rural Chinese women in the early twentieth century did not marry to a wealthier household, and outside of Sichuan, footbinding did not guarantee a better marriage. Thus, for the one-third of women who did marry "up," hypergamy was largely independent of footbinding.

We examine the transfer of brides among rural households in China's preMaoist society for several reasons. First, to understand Chinese gender relations, we should view realistically what opportunities for socio-economic mobility in marriage existed for the majority of women. Our data come from rural communities at a time when the Chinese population was overwhelmingly rural. Most rural marriages were with other rural families at such close distances that women were able to maintain contact with their natal families (Bossen 2002; Judd 1989). Second, to understand footbinding beyond the elite, we need to set it in the context of normal, rural life (Blake 1994, 699n21). Women whose lives we discuss were rarely among the elite. For example, only twenty-eight out of 4,180 women interviewed who were ever footbound (hereafter "everbound") were bound by a servant or wet nurse. (The database is explained below.) Third, our analysis shows the importance of examining large bodies of empirical evidence before accepting popular explanations or beliefs that imply social causality. Our findings indicate that, despite one regional parallel to Cinderella, marriage mobility had little to do with footbinding in early twentiethcentury rural China.

\section{Bound FEeT: A RANGe}

Details of the painful process of footbinding (缠脚, 裹足, 包脚) have been reported by scholars and in novels (Blake 1994, 682n6; Jackson 1997, 32 - 38; Levy 1967, 26-28, 210-41; See 2006, 14-34; Yao 1936, 59-63). To achieve

\footnotetext{
${ }^{1}$ In addition to evidence provided here, Gates (1989, 2001, forthcoming) and Bossen (2002) have shown that footbinding was not limited to the well-to-do. For footbinding portrayed as a means to marriage, see for example Pruitt ([1945] 1967, 22), MacGowan (1913, 25-26), and Levy (1967, 210, $211,218,228,234,238,246,249,252)$. Dorothy Ko acknowledges the ethnographic basis for what she calls the "marrying-up' thesis" $(2005,3)$ and readily accepts the institution of marriage as crucial to the perpetuation of footbinding $(54,57,182$, implicit in 188). However, she dismisses hypergamy as a general explanation of footbinding, saying it is "applicable primarily for the modern period - after footbinding had undergone a sea change in its social composition-when the majority of practitioners were peasant women" (4).
} 
much-lauded "three-inch" lotus feet required bending the small toes under the foot and toward the heel, forcing the arch upward. (Three "inches" [ able measurement roughly 5 US inches or 10 centimeters.) Over time, often several years, the process led to pressure breaks in the arch as well as the toes, and some women reported loss of toes; women whose arch had been broken could not be completely unbound without disastrous results (Fielde 1887, 27-29; Levy 1967, 92, 208-10, 214, 216-17, 233, 277-78). Not all women experienced such an extreme process. A less restrictive form of footbinding, sometimes called “cucumber” (黄瓜脚) or “half-sloping” feet (半坡脚) existed. ${ }^{2}$ It also required forcing the toes under the sole, eventually breaking the toes, but it did not break the arch. Many women we interviewed experienced binding as a phase of their lives-binding for a period and later unbinding. As long as the bones of the arch were intact, let-out feet would - after a painful transition periodreturn to forms that functioned much as never-bound feet (Levy 1967, 21617, 277-78; Melissa J. Brown, field notes).

\section{Expectations and Folk Beliefs}

Chinese families often hoped to marry their daughters into a life better than their natal homes could provide for them. In the laments commonly performed before marriage by brides and their close kin, the consequences for a girl's happiness of both upward and downward marriage were thoroughly explored: from having better food and clothing to laundry arrangements that kept one's feet dry (McLaren 2008).

Gates, Bossen, and Brown have collected interviews from thousands of elderly Chinese women, which included asking why feet were bound. Most who responded had been bound themselves. One of the most striking things about these responses (see table 1) is their plurality, even though many women gave more than one explanation of footbinding. ${ }^{3}$

Tradition (传统), custom (习俗), and popularity (流行, 个个兴, etc.) 一the most common responses — are essentially peer-pressure explanations. Anthropologists

\footnotetext{
${ }^{2}$ Dorothy Ko $(2005$, 193-95) emphasizes the temporal aspect of the range of variation, portraying the "golden lotus" (金莲) as a "modern" version and the looser bindings found during the early twentieth century as influenced by the custom's demise. Ko $(183,193-94,280 \mathrm{n} 79)$ herself reports on such looser bindings from earlier centuries but interprets the non-lotus feet as "poorly bound." She does not consider if they might indicate the presence of a range of binding at that earlier time. ${ }^{3}$ These responses occurred in structured interviews, when women were asked "why bind feet" (为什 么缠足) or, in Sichuan, "what was the most important reason your family bound your feet" (你家给你缠 脚最重要的原因). (In the former question, multiple answers were allowed in the coding of the response. In Sichuan, only one answer was allowed.) In some sites, we also requested women to give local sayings about footbinding. In other sites, ever-bound women were asked what explanation their mothers gave when binding their feet (86 percent of 4,180 respondents were bound by their mothers).
} 
Table 1. Responses to Why Bind Feet?

All women, regardless of marriage date.

\begin{tabular}{lrccc}
\hline & $\mathrm{n}$ & $\begin{array}{c}\text { Appearance or } \\
\text { Beauty }\end{array}$ & Marriage & $\begin{array}{r}\text { Tradition, Custom } \\
\text { or Popularity }\end{array}$ \\
\hline Central & 159 & $45.9 \%$ & $33.3 \%$ & $44.7 \%$ \\
North & 440 & $33.4 \%$ & $34.8 \%$ & $74.1 \%$ \\
Sichuan & 3300 & $12.1 \%$ & $34.8 \%$ & $48.7 \%$ \\
Southwest & $\underline{274}$ & $\underline{12 \%}$ & $\underline{50 \%}$ & $\underline{60.2 \%}$ \\
All & $4 \overline{173}$ & $15.6 \%$ & $35.7 \%$ & $52 \%$ \\
\hline
\end{tabular}

For explanation of all tables, see the appendix.

often elicit such responses when asking about motivations, because people are rarely self-reflective (Brown 2007, 117). Appearance (漂亮, 美丽, 好看) did not merit much stock overall, though in the Central region where it was most popular, appearance was often linked to shame (an indirect reference to popularity) and to marriage prospects. There was a common story in Jiangxi and Hubei that never-bound feet make a bed like a grave, because the woman's large feet stick up like a tombstone. ${ }^{4}$ This story provided a clear message to avoid the mortification of large feet, which would symbolically turn a marriage bed into a death bed.

Of the women who were interviewed, 35.7 percent linked footbinding to marriage. The sayings "no one would want" a not-bound girl for a daughter-in-law (大脚没人要) and “no footbinding, no marriage" (不裹脚嫁不掉) were frequently repeated. In Luliang County of Yunnan Province, sixteen women (of fifty-four who referred to marriage as an explanation for footbinding) used one of these two phrases. Some women blamed the purported requirement on "feudal society," some blamed their in-laws, a few mistakenly blamed the Nationalist government. ${ }^{5}$ Given that 99 percent of all the women we interviewed married, and only 66 percent of women married by 1949 had ever bound their feet, the necessity of footbinding for marriage was clearly false.

Though we asked about the link to marriage, some women responded that "footbound women marry well." 6 To marry well might imply that a woman's husband was a man of ability and promise, or that her prospective mother-in-law

\footnotetext{
${ }^{4}$ For example, Jiangxi JX ID \#2302083: “脚大, 在床上像立着一块墓碑” (large [unbound] feet stick up in bed like a tombstone).

${ }^{5}$ ID \#3102004: “旧社会, 不襄脚嫁不掉” (in the old [feudal, pre-1949] society, no footbinding [meant] no marriage); ID \#3102066: “豪了拆了, 后来要做媳妇了, 听说婆婆家个个是小脚, 自己才拉的裹了” ([I was] bound and unbound; it was only later, when I was going to be a bride and heard that [at] my mother-in-law's, all [the women] were footbound, that I bound [my feet again]); ID \#3012069: “大脚没人要. 国民党叫裹” (no one wanted not-bound [women]; the Nationalists ordered binding).

${ }^{6}$ For example, Guizhou AS ID \#1501194: “脚小的女人好嫁”; Hebei QF ID \#1701048: “[脚小]能嫁得 好.”
} 
and sisters-in-law were kindly and reasonable, or that the marriage might take the bride from a less to a more desirable environment-from a rough mountain village to a prosperous valley town, for example (Bossen 2007). The core meaning of a "good marriage," however, was one that transferred a girl to a marital family with better resources than those of her natal family: "Bind the feet small, then landlords and wealthy families will come to speak [about a match]."7 A good marriage helped her escape the labor burdens that fell to young wives in families at the bottom of China's hierarchy.

Folk sayings made this aspect of marital desirability clear and threatened downward mobility if not bound. "Those who marry to Shuangqiaoying [a local town considered wealthy in the rural hinterland] all have bound [lotus] feet; those with half-sloping feet only have water to eat," or "bind feet, become a bride; don’t bind, become a slave." Girls who submitted to footbinding were supposed, at least, to be married as a formal wife, with a wife's rights and duties, rather than transferred as a concubine without even the right to claim motherhood of her own children, or rented or sold as a bond servant or prostitute (Hershatter 1991; Jaschok 1988; Watson 1991).

This distinction between leaving one's natal home in formal marriage or in some other fashion was emphasized in various ways. Women interviewed referred to this distinction, sometimes in economic terms, as when a woman specified her orthodox marriage by stating the dowry and/or bride-price her marriage entailed, and sometimes in symbolic terms, as when a woman specified the kind and color of sedan chair in which she crossed from daughter to wife, the time of day she made the crossing, and the very doors through which she passed in transit. The cultural message was that most women's marital wealth-trajectory was and should be upward, and thus movement downward was shameful. "In the past, only brides with bound feet could ride [to their wedding] in sedan chairs"; "people made fun of big [not-bound] feet." Hypogamy (marrying down) was decried, yet we shall see that by the measures we apply here, it was relatively common-about one in five women. That women saw hypogamy as an offense was made clear by the resentment voiced against such marriages (see the example of Ms. Wang below) and sometimes against parents who arranged them.

A different folk formulation about marital outcomes contradicts this cultural vision of hypergamy. The saying “doors match, households align” (门当户对) underlines the folk belief that marriage for women need not marry up, nor should they be married down; too great a difference in prosperity might result in embarrassment on both sides. The core meaning is a directive against hypogamy: a girl

\footnotetext{
${ }^{7}$ Yunnan LL ID \#3102027: “脚小了大地主有钱人家[就]来说 [媒].”

${ }^{8}$ Yunnan JC ID \#3103155: “嫁到双桥营的都是小脚、半坡脚才得水吃.”“裹脚当新娘、不裏脚当婢女” is a phrase uttered spontaneously in Fujian, Sichuan, and Jiangnan, and widely recognized.

${ }^{9}$ Yunnan JC ID \#3103176: “以前新娘都要小脚才能坐轿子.” Henan ZK ID \#1902074: “别人笑话大脚。”
} 
should not be married into what she would experience as poverty and extraordinary demands on her body (i.e., significantly worse than her natal family).

Loving families planning a girl's marriage took her rights and labor expectations seriously, but marriage was a family, not an individual, matter. A girl's personal advantages might have to be sacrificed (Gates 1996). The broader problem of an alliance between two households that would be beneficial, or at least not harmful, to both also factored into nuptial plans (e.g., Cohen 1976, 2005; Judd 1989; Wolf and Huang 1980). This aspect of marriage choice suggests strong motivations to match doors which, if widespread, would disrupt any general tendency for female hypergamy. Preferences for marriages of equals run counter to the economic opportunities provided by the male-biased population sex ratio to the families of women.

There were "chronic shortages of marriageable women" in late imperial China, with an estimated 15 to 20 percent more marriageable men than women (Sommer 2000, 13; Telford 1992, 24-25, 33). "Though the severity of the shortage varied sharply from one area of the country to another, it is fair to say that under the traditional [i.e., late imperial Han kinship-marriage] regime, women were in short supply everywhere in China ... [which] created a universal competition for wives" (Wolf and Huang 1980, 140). Such competitionespecially combined with the persuasive skills of well-networked older women who served as semiprofessional matchmakers (媒人; Wolf and Huang 1980, 275) — suggests that families with marriageable daughters could benefit economically from marrying their daughters up (Mann 1997, 12-13).

What are we to make of these differing expectations? Economic tactical considerations in conjunction with demographic male bias suggest hypergamy. Cultural beliefs suggest both hypergamy and the marriage of equals. The frequency of folk sayings that encapsulate contradictory views ("many hands make light work" versus "too many cooks spoil the broth") suggests that considerable effort may be required to understand what each apparent opposite truly means. Are different positions held by differently situated parts of the population who voice them? Are people's nuggets of popular wisdom simply detached from actual experience: smooth, unthinking responses to troublesome and unanswerable questions? Or is our perception of opposition simply the result of incomplete contextualization? How do we understand variation in beliefs that encompass what appear to outsiders as contradictions?

Our approach is behavioral rather than discursive. We have data on the marriages of substantial numbers of rural women who lived when footbinding was common and thus can analyze whether footbinding had the upward mobility effects often ascribed to it. We interpret the folk beliefs that "footbinding leads to hypergamy" and "marriage should be between equals, or at least not downward" as bearing on the material consequences of a bride's marital move, not on her sexual satisfaction or the companionability of her husband. Each proverbial position expresses a bride's hope that she will be better off, or at least not 
worse off, through marriage. The two positions differ in an extremely important, gender-asymmetrical way, however. One depended on a crippling process enforced on girls too young to truly grasp threats such as granite-quarrying or sex work. The other ignored the girl's attributes to focus on the two families to be linked as affines. Each had a very different implication for the behavior and control of the girl herself.

\section{Two Women in Their Context: Ms. Wang of Hubei, Ms. Xu of Sichuan}

The example of Ms. Wang (not her real name), from a rural township in Huangpi District in Hubei, formerly about two days' walk from Hankou, violates many of the expectations about the hypergamous possibilities of footbinding and at the same time demonstrates some of the complexities facing our efforts to interpret causal factors in women's life trajectories. ${ }^{10}$ Wang was born in 1926 to a family with about $7 \mathrm{mu}$ (亩) of land (about 1.15 acres or 0.47 hectares), a draft ox, and a house. Her father spent most of his time making a local kind of sugar for sale. We do not know the scale of this business, but details of Wang's life suggest that he did not hold a commanding position in his family. Wang's mother, who was footbound, spun and wove on her own loom; Wang and her older sister each had a spinning wheel. Her mother died young, leaving three children: Wang (age six or seven), her older sister (fifteen), and her younger brother. Her mother had bound the older sister's feet at age twelve, which was rather late. Although Wang was bound at about the average age, her experience of footbinding was very unusual, because it was done by a man, and a man who was not even her father-when Wang was about eight years old she was bound by her mother's brother.

Wang spun and eventually wove better than her older sister who was married out at seventeen, about the customary age. As an unmarried daughter, Wang became a crucial economic support of her family. She spun cotton, 4 to 5 "big ounces" (两) of cotton in a day, which she then wove into cloth. ${ }^{11}$ She could make a strip of cloth about 1.5 feet across and 10 feet long (45.7 centimeters $\times$ 3 meters) in a day-enough to make one top or a pair of pants. Some cloth she made into clothing for the family (about thirty-two clothing items per year); some were sold for cash or exchanged directly for household items like cooking oil. Her production figures rank at the high end of those we have assembled for thousands of women in thirty-three widely spread sites. In addition to cotton, Wang also spun hemp at the rate of about 3 big ounces in a day, as hemp is a very different

\footnotetext{
${ }^{10}$ Although discussed here qualitatively, Ms. Wang [Hubei HP ID \#2001017; Melissa J. Brown, field notes, July 12-13, 2009] does not appear in the quantitative calculations because she married after the 1949 cut-off for the sample used in the tests.

${ }^{11}$ Four to 5 两 was about $0.33-0.42$ pounds or $0.15-0.19$ kilograms, because at that time, there were 16 两 in a 市斤.
} 
fiber, harder to spin. The hemp yarn she wove into grain bags (cf. Mueggler 2001, 15). Each bag was sold in Hankou (by her uncle) for 1.5 yuan (元), which at that time and in that place could buy about $80 \mathrm{jin}$ (市厅) of rice, an amount of staple food enough for a family of eight for ten days. ${ }^{12}$ Although her family had a sugar business and land worked by her father, uncles, and younger brother, Wang was confident that she was a major-if not the main-source of cash income in her family. She reported that, based on her experience, girls who spun and wove not only paid for their own upbringing but could support their families.

Wang's relatives did not arrange a marriage for her until 1950 — when she was twenty-four years old! — even though girls in this area and age group married at about eighteen years old. Her uncle arranged the match, taking on a responsibility that normally would have fallen to her father-another hint that the father held an unimpressive position in the kin group. She married to a much poorer family, one (later) officially classified as poor peasant. Before 1949, her husband's family had no land, no house, no loom, no spinning wheel, and only shared a cow. They had lived by collecting wood in nearby mountains and making it into charcoal for sale. Wang brought a spinning wheel as part of her dowry, but did not bring her loom because its size made it too hard to move so far. With collectivization, she let her feet out of their bindings to work in the fields. Although she had never done agricultural labor as a girl, under the new regime, many women unbound their feet (voluntarily or otherwise) and engaged in agriculture. Thereafter, she could spin only at night, but she continued to do so-renting another family's loom four to six times a year-through the 1970s in order to make clothing for all nine members of the family.

When Brown interviewed Wang at the age of eighty-three, in a recently constructed home bustling with her sons' children, Wang still resented having been married "down." Asked if her husband's family had land, she said emphatically that they were too poor (穷), her marital family was a bad one (婆家不好), she still was not used to the life (还不习惯婆家生活), and her natal family was better (娘家好). Brown asked why her father and uncle had found her such an illmatched family to marry into. Wang said she did not know. Her dowry was impressive: over 100 items of clothing and more than twenty pairs of shoes (all of which she made herself), a jade bracelet, several large pieces of furniture, a spinning wheel, and enough of her own "private" money (私房钱) to build a house.

Her large dowry argues that whatever the structure of her natal kin group, they were not poor, and that their prosperity depended in part on her work. In some Chinese contexts, at marriage an exceptionally productive daughter had a substantial claim on what she had made and earned during her maidenhood (Gates 1993). Nevertheless, neither Wang's bound feet nor her value in her natal family translated into a "good" marriage. Her hypogamy may have resulted

${ }^{12} 80$ 市斤 was about 106 pounds or 48 kilograms. 
from any one (or all) of several factors. War and regime change may have delayed the normal order of events. Her kin may have feared revolutionary reprisals against the prosperous "bad class" households in which she might have found a more suitable marital home. Or the delay of six years past the customary marriage age may have meant that her family was reluctant to part with such a good worker (cf. Judd 1989; McLaren 1998; Stockard 1992; Wolf and Huang 1980). It seems likely that Wang's kin found it difficult to arrange a marriage for such an old bride.

Ms. Xu of Suining, Sichuan, born in 1915, was bound at six by her mother who, along with her maternal grandmother, insisted on it lest she not "find a mother-in-law" (Hill Gates, field notes, 1992, p. 107). Her father, angry because "they were crippling her," beat her mother, but the mother gave up only when her daughter was fifteen and still stubbornly unwilling. "I just won't bother about her anymore," she said. Xu herself was delighted at her new comfort, unconcerned about her marriage prospects, and even willing to carry water for the family - a heavy task that girls generally hated. In the meantime, making the "footbinding leads to a better marriage" argument quite irrelevant, a childhood cross-cousin betrothal (娃娃亲, 子妹开亲) was arranged with her mother's brother's son. This was not an undesirable marriage. It kept the daughter close and, in Sichuan, exemplified the concept of "matching doors."

As a girl, $\mathrm{Xu}$ was kept busy caring for six household children during the day. She also became an able spinner capable of producing 1 big ounce every night, working by the light of the moon or an incense stick stuck in her footbinding tapes. Five of these ounces traded for 7 of rice, close to an appropriate staple ratio for a girl. She learned sewing as well. Unfortunately, we have no information about her dowry except to note that Sichuan dowries were important marital transfers, paid for from a girl's own work and/or the resources of her natal family - that is, not paid for or supplied by the groom's family. Most women with Xu's skills married with trousseaux from their own handwork.

Not long after she married at age twenty, she began to make layettes for women to send to their married daughters in the three days after a birth. Ideally, a layette comprised all the clothing and bedding a baby needed until it was six years old-another way in which a woman's natal family continued to support her after marriage. An ordinary set might have twenty or thirty pieces of clothing, perhaps recycling some used material. Rich families ordered larger sets taking several months and 60 yuan (元) of new cloth to complete. $\mathrm{Xu}$ ate and worked in the pregnant woman's mother's house where the employer could supervise the quantity and quality of her work. In addition to her food, she received a silver dollar (大洋) monthly, an amount that would easily have bought 100 jin (斤) of staple grain. This career served her well when her husband was shanghaied into the army and her two children died as toddlers. Living without children to care for, she also learned to spin with a larger, more efficient wheel, producing 2 jin (斤) of cotton yarn in “a day and an evening” (一天一夜). This income enabled her to support herself with spinning alone. 
Although Xu's kinswomen had stressed the stereotypical cultural reason for footbinding her, it appears that her well-being had depended more on her own skills and initiative than on "marrying well." Her nine years of binding, however, may have laid the foundation for her productive application of effort.

Wang and $\mathrm{Xu}$ knew from experience that women working at classically female tasks could earn enough not only to support themselves but also to buy foodstuffs for a whole family and, of course, to clothe them. Their lives exemplify a strong relationship between homemade textile goods and footbinding.

\section{Historical Sources}

Most historical data about footbinding has been written by and about the elite. Yao (1936) put together a nostalgic compendium of footbinding, which presented it as erotic. Levy (1967) translated literary references and anti-footbinding writings (largely from Yao) and interviewed a dozen elderly women in Taiwan in 1960-61, continuing the presumption of footbinding as related to sexuality, beauty, and marriage (see also Gao 1995; Greenhalgh 1977; Ke 1995; Ko 2005; Wang 2000). Ko $(2005,188)$, after stating that much of footbinding's history can only be retrieved through the writings of men, attributes its origins unequivocally to its appeal to men. Gates (2008), however, provides a counterview, using evidence from Chinese erotic art and literature that footbinding was not so ubiquitously erotic, even to the elite.

Erotic and aesthetic appeal are elite rationales for footbinding, for it was widely believed that footbound women were not economically productive: footbinding was "an impediment to the actions of women" (McLaren 1998, 6; cf. Buck 1937, 1:292; Davis 1836, 1:255-56; Greenhalgh 1977). Newspaper reports primarily about elite, urban women that appeared as part of antifootbinding movements frequently cited women's inability to spend time on their feet, for example to wait on a mother-in-law; some noted women's inability to flee from bandits (Levy 1967, 210-38). In our interviews, women mentioned a fear that footbound women could not flee invading Japanese military forces. If women could not move, how then could they work? The famous reformer Liang Qichao was so influential that his "image of women with bound feet as parasites, beasts, and slaves [became] the standard view" (Ko 2005, 21). Many women we interviewed had internalized these attitudes (cf. Jacka 1996, 145), as women who spun, wove, or worked in the fields often did not consider their contributions productive: I "spun, didn't work, didn't walk."13

In the absence of hard numbers, estimates of the percentage of Chinese women who bound their feet are contradictory. Many both declare the ubiquity of footbinding for Chinese women and qualify the footbinding of poor women as

${ }^{13}$ Jiangxi PZ ID \#2301149: “就纺线, 不做事, 不走路.” 
less common or more loosely bound. ${ }^{14} \mathrm{~A}$ rare, reliable source on population distribution of footbinding-general statistics by the Japanese colonial government in early twentieth-century Taiwan-indicates neither strict class division nor ubiquity: in 1905, 68 percent of Taiwan's Hoklo female population had bound feet (Brown 2004, 156).

Interpretations of footbinding as a custom meaningful to women (Ko 2005; Wang 2000) are only possible with the recording of Chinese women's voices on this topic. Such recordings occurred relatively recently-in the late nineteenth and early twentieth centuries_ _ as footbinding was already ending as a practice, and as it was being held up as shameful by Chinese political reformers, the Chinese Communist Party (CCP), and Westerners. ${ }^{15}$ Chinese women's voices recorded are primarily those of elite women, with those of a few poor Christian converts whose words were passed on by missionaries (Pruitt [1945] 1967). Such women were trying to make sense of the painful process done to themusually by mothers-before the age when children fully comprehend adult reasoning and explanations (see footnote 3 ). Their views provide a window on people caught in sweeping social changes and must be understood in this context, including the timing of when they spoke (Ko 2005, 13). Their attempts at understanding what happened to them and why must be reconciled with other types of information about footbinding, but given the limitations of historically recorded information about the lives of most Chinese women, ever-bound women themselves are the best sources.

\section{Sources of the Empirical Data}

We collected data about girls' and women's labor, marriages, and footbinding directly from elderly rural women who were interviewed about their own experiences and those of female relatives whom they knew by sight. Hill Gates began this project in the early 1990s with a large survey in Sichuan and a smaller one in Fujian (Gates 2001). This paper uses Gates's Sichuan data, collected in ten different counties from almost 5,000 women (approximately 500 women per county), pooled as "Sichuan" sites.

Previous research by Laurel Bossen, who studied footbinding in relation to rural women and development in Yunnan (Bossen 2002), and by Melissa

\footnotetext{
${ }^{14}$ The following sources, for example, declare the ubiquity of footbinding and qualify its practice among the poor: Levy (1967, 274, 283, 284), Greenhalgh (1977), Ko (2005, 3-4, 21, 34, 202, 228), and Appiah (2010). Fielde (1887, 31) estimated 90 percent of Chinese women had bound feet, but also suggested that footbinding was "not so much a matter of class but of locality" (cf. Gates 2001). Blake (1994, 702) also declared the ubiquity of footbinding without numbers, though he argued, following Gates (1989), that footbound women were productive.

${ }^{15}$ Those who were publicly known for considering footbinding shameful include Kang Youwei, Liang Qichao, Mao Zedong, and Mrs. Archibald Little (who founded the Natural Foot Society 天足會).
} 
Brown, who studied footbinding in relation to ethnic identity in Taiwan and Hubei (Brown 2004), demonstrates the significance of footbinding from many perspectives. Together, Brown, Bossen, and Gates have surveyed a wider area of rural China to collect comparable data on girls' and women's labor, marriages, and footbinding at twenty-three sites in eleven provinces outside Sichuan. In each site, we surveyed 100-200 elderly women born early enough that they or their peers would have been subjected to footbinding. Quantitative data on almost 1,100 women from eleven counties in Anhui, Henan, Hebei, Shanxi, Shaanxi, and Shandong are pooled as "Northern" sites. Quantitative data on about 700 women from four sites in Jiangxi, Hubei, and Hunan are pooled as "Central" sites, and quantitative data on about 500 women from three sites in Yunnan and Guizhou are pooled as "Southwestern" sites. All communities surveyed were Han (the ethnic Chinese majority).

Our data show, not surprisingly, that footbinding generally decreased over time. Because Gates's Sichuan survey was conducted fifteen years earlier than the surveys in other regions, it includes more women born earlier (compare figures 1,2, and 3). These data illustrate that, throughout the early twentieth century, the decline of footbinding in different localities was not uniform (see figure 1). Trends in different Sichuan counties were not always parallel. Moreover, with sample sizes of 500 , we can be certain that this county-level variation is not just random "noise." The percentage of girls still being footbound was 40 or higher in all counties through the cohort born 1920-24. In Ba (BX), Mingshan (MS), and Longquan (LQ) counties, footbinding actually increased in the 1910-14 birth cohort; footbinding also increased in Emei Shan (EM) in the 1925-29 cohort. In most counties, footbinding stayed over 60 percent through the 1915-19 cohort. With an average age at footbinding in Sichuan of 5.8 (across 3,305 women), these bindings occurred between 1920 and 1925.

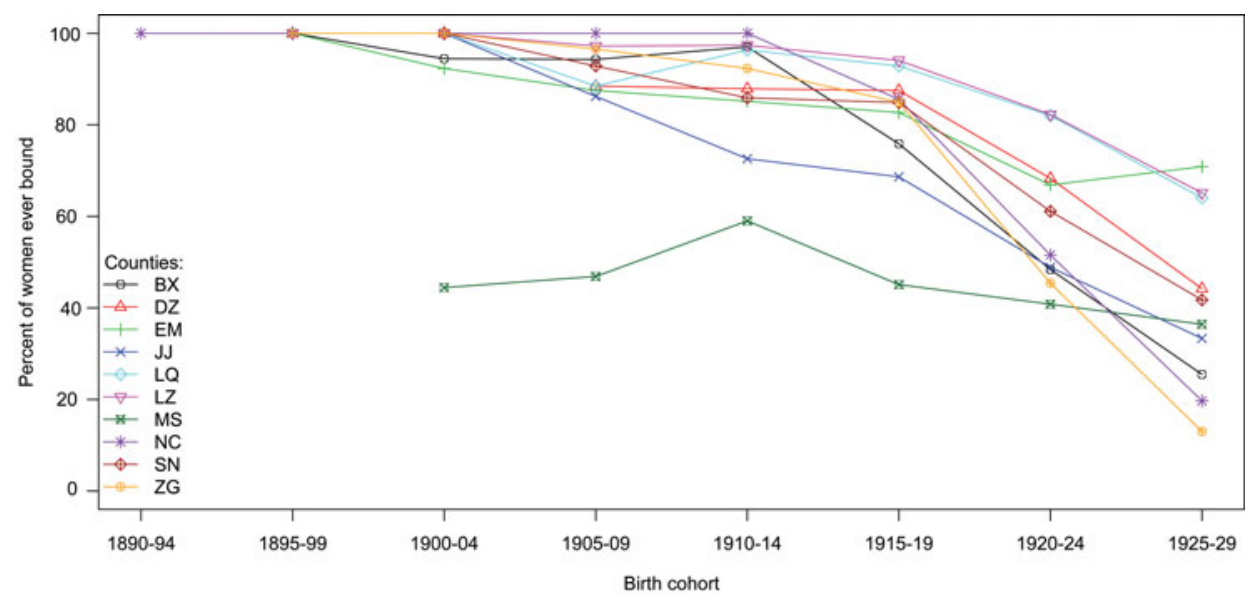

Figure 1. Percentage of Women Ever Bound in Ten Sichuan Counties, by Birth Cohort

Source: Gates project data. 


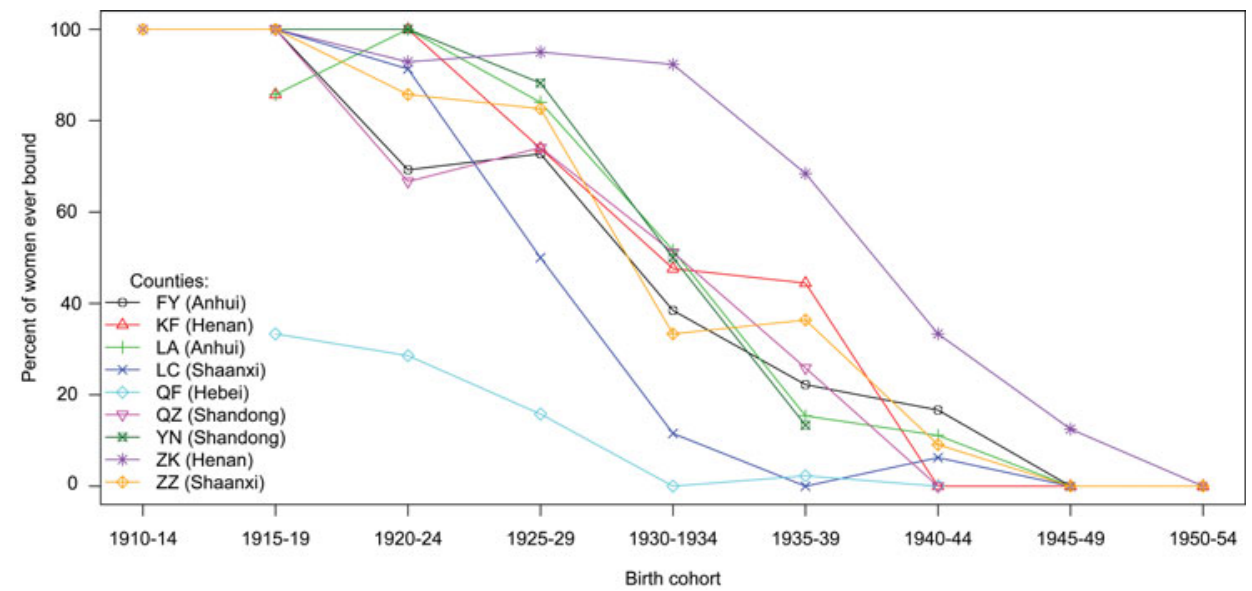

Figure 2. Percentage of Women Ever Bound in Eleven Northern Counties, by Birth Cohort

Source: Brown-Bossen-Gates project data.

We see similar trends in the Northern sites (see figure 2). The numbers of women interviewed in each of the Northern sites are smaller, but the percentage who were footbound is high (over 65 percent) for all sites except Qingfeng, Hebei (QF), and Luochuan, Shaanxi (LC), through the cohort born 1925-29. In the Northern cohort born 1930-34, the percentage drops sharply, bringing all sites at or below 50 percent except Henan's Zhoukou (ZK), where the decline in footbinding does not drop below 50 percent until the 1940-44 cohort.

The Central sites (see figure 3) show earlier declines. By the 1925-29 birth cohort, both Hunan's Anxiang (AX) and Jiangxi's Jinxian (JX) are well under 40 percent, and Jiangxi’s Pengze (PZ) is already approaching 50 percent.

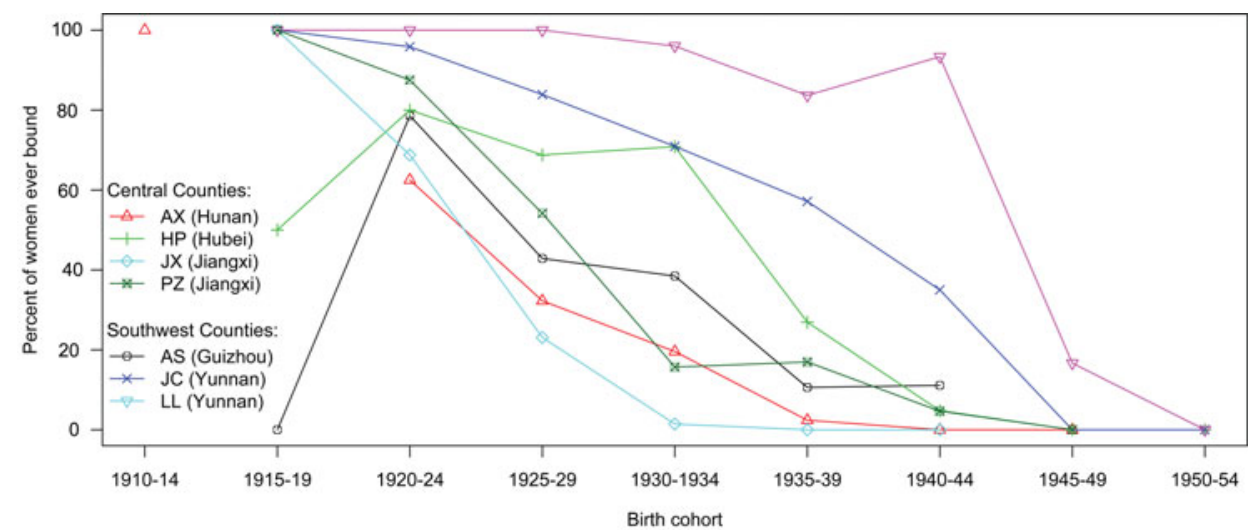

Figure 3. Percentage of Women Ever Bound in Four Central and Three Southwestern Counties, by Birth Cohort

Source: Brown-Bossen-Gates project data.

Note: The 1915-19 birth cohort has extremely small samples $(0<\mathrm{n}<7)$, so rates for this cohort are not likely to be representative of the footbound population in the past. 
Only Hubei's Huangpi (HP) stays over 60 percent through the 1930-34 cohort. Of the three Southwestern sites, Guizhou's Anshun (AS) falls in the Central region range, while the two Yunnan sites show higher rates. Yunnan's Luliang (LL) stands out in these two regions as maintaining the highest rates of binding (over 80 percent) for the longest time-through the 1940-44 cohort. Given an average age of binding at eight (across 298 women), these bindings were occurring right up to the establishment of the Communist government.

In order to test for hypergamy in the population, and as affected by footbinding, we selected a sample from the 7,314 women surveyed in these sites that was governed by three conditions. First, we included only first marriages for women (over 99 percent of all women surveyed married), because these were the marriages arranged by a woman's natal family. Second, we focused on women who had been born in a context where they experienced local expectations about footbinding not yet weakened by strong negative pressures. The relationship hypothesized between footbinding and hypergamy was less likely once footbinding had become a minority practice than when footbinding was the norm. Therefore, we included only those birth cohorts in which the majority of women were bound. Third, when comparing the possible effect of footbinding on hypergamy, we broke the sample into women whose feet were ever bound, women whose feet were bound and let out before marriage, and women whose feet were never bound. For reasons given below, we consider only women whose feet were still bound at marriage as "bound" in the hypergamy tests presented here.

To fulfill our second condition, we could not draw a sample across all the sites simply on the basis of a single year of birth, since footbinding began to decline at different times in different sites. Instead, we selected women with bound feet who were born in five-year birth cohorts when at least half $(50$ percent or more) of the girls born in that cohort were ever subjected to binding. These "majority cohorts" represent reasonably well local climates of opinion that prevailed prior to strong political and economic anti-footbinding pressures and allow us to compare across space and time. For example, using majority cohorts, we removed the data from the youngest one or two age cohorts in six Sichuan counties, and we used data from only one birth cohort in Mingshan.

We developed this "majority cohorts" approach due to the temporal variation in political economy across the areas in our comparison. Some areas under Nationalist, warlord, or CCP political control felt anti-footbinding pressure earlier than others. The Jiangxi sites (JX, PZ) were under firm Nationalist control before these troops fled the Japanese invasion in 1938. The warlord Yan Xishan controlled our Changzhi city district site in Shanxi (CZ) from the 1920s. ${ }^{16}$ The site of Luochuan County in Shaanxi (LC) was not far from the Communist base of Yan'an (Bossen et al. 2011). However, during the Japanese

\footnotetext{
${ }^{16}$ Dorothy Ko $(2005,50-63)$ discusses Yan’s anti-footbinding campaigns.
} 
war (1937-45) and again during the civil war (1945-49), discouraging footbinding had a low priority for these regimes. Nor did "Liberation" - the date of control by the CCP-occur in the same year everywhere. People in Jiangchuan, Yunnan (JC), reported being liberated in 1952 (Melissa J. Brown, field notes). Even after Liberation, the binding of little girls did not always cease at once. Bossen interviewed in Yunnan villages where the last new bindings occurred in the 1950s (Bossen 2002, 2008). The strong push in the late 1950s to get women out of purely domestic institutions and into increasingly socialized forms of work marked the end of all new bindings. ${ }^{17}$

A great many women were bound in the areas we surveyed, but in fact, most bindings were not maintained (see table 2). In the Sichuan, Northern, and Southwestern sites-where footbinding was common among the women we interviewed-roughly 70 percent of women who married by December 1949 had ever had their feet bound (with a range of 67 to 74 percent) and roughly 35 percent of these ever-bound women were still bound at the time of marriage (with a range of 33 to 38 percent). The Central sites show considerably lower rates of women who were ever bound (41 percent) and far fewer-only 15 percent-who were still bound at marriage. These numbers bear out interview reports in the Central region that it was the generation above-their mothers and mothers-in-law_who had bound feet. These figures showing large percentages of ever-bound women who let out their feet before marriage suggest that something other than marrying well was going on.

Some families accepted a small girl's refusal to stay bound relatively quickly: "My father allowed me [to unbind] because my feet hurt, so I didn't have to bind my feet." 18 In other families, a girl's “stealthily unbinding” (偷着放, Anhui FY ID \#1102030)_for example, loosening or removing the binding cloth at night under the bedcovers - was the subject of years of dispute, as in the case of Ms. Xu. Women in the Sichuan survey who had been bound themselves were asked about their attitude (态度) to footbinding. Their responses are striking: 44 percent of 3,302 respondents said that they resisted (反抗); only 20 percent said that they agreed (同意) (the remaining 36 percent answered "did not know” [不知道]). Such resistance is also captured in Carma Hinton's film, Small Happiness, when three elderly women in Low Bow Village (in Shanxi) are asked if they wanted to have their feet bound, and after a pregnant pause, they all burst out angrily. One woman's voice takes over, explaining that they

\footnotetext{
${ }^{17}$ For discussion of women's labor in the collective era, see, for example, Jacka (1996), Eyferth (2009), and Hershatter (2011). Some modernizing urbanites in east coast cities ceased to bind in the late nineteenth and early twentieth centuries (Ko 2005; Mackie 1996). Did women of the urban working classes follow them? No quantitative evidence exists, but anecdotal evidence suggests that they did not (Fielde 1887, 27-32; Pruitt [1945] 1967). Taiwanese under Japanese colonial rule ceased binding altogether about 1915, due to strict police enforcement (Brown 2004, 2010).

${ }^{18}$ Hubei HP ID \#2001071: “父亲认为脚疼, 所以不让包脚.”
} 
Table 2. Footbinding Status of Women Interviewed.

All women marrying no later than December 1949.

\begin{tabular}{|c|c|c|c|c|c|c|c|}
\hline Region & $\mathrm{n}$ & $\begin{array}{c}\text { Ever Bound } \\
(\% \text { of } \mathrm{n})\end{array}$ & $\begin{array}{c}\text { Never Bound } \\
(\% \text { of } \mathrm{n})\end{array}$ & $\begin{array}{c}\text { Bound at } \\
\text { Marriage (\% of } \\
\text { Ever Bound) }\end{array}$ & $\begin{array}{c}\text { Unbound } \\
\text { (\% Ever Bound) }\end{array}$ & $\begin{array}{c}\text { Unbound Before } \\
\text { Marriage (\% of } \\
\text { Ever Bound) }\end{array}$ & $\begin{array}{l}\text { Bound After } \\
\text { Marriage (\% of } \\
\text { Ever Bound) }\end{array}$ \\
\hline Central & 233 & $95(41 \%)$ & $136(58 \%)$ & $14(15 \%)$ & $87(92 \%)$ & $58(61 \%)$ & $1(1.1 \%)$ \\
\hline North & 415 & $289(70 \%)$ & $123(30 \%)$ & $110(38 \%)$ & $255(90 \%)$ & $145(50 \%)$ & $1(0.3 \%)$ \\
\hline Sichuan & 4875 & $3259(67 \%)$ & $1616(33 \%)$ & $1100(34 \%)$ & $2543(78 \%)$ & 2094 (64\%) & $3(0.1 \%)$ \\
\hline Southwest & 198 & $143(74 \%)$ & $50(26 \%)$ & $47(33 \%)$ & $127(93 \%)$ & $79(55 \%)$ & $3(2.1 \%)$ \\
\hline
\end{tabular}

For explanation of all tables, see the appendix. 
had no choice. For large numbers of individual girls, their footbinding ended not when they began to resist, but when their families accepted their resistance and ceased rebinding them.

Much early unbinding in our samples represents a pattern in which girls' feet were bound without breaking the arch. In Fujian, women said this was done for the mother-in-law to see (给婆婆看), with the bride then unbound permanently shortly before or after marriage. This pattern-also occurring in Sichuan's Mingshan and Emei Shan counties as well as in the Tujia area of Enshi in Hubei-may reveal the fading of a formerly more rigorous custom, but it could also be a common, local variation based on the expectation that both young girls and new wives would sometimes work at jobs for which bound feet were inefficient (Gates 2001). Fujian girls in coastal villages, for example, rummaged shin-deep in tidal mud flats for shellfish. Comments from women elsewhere in this study suggest similar concerns. "I had to plant [crops], do work, so [my mother] never bound my feet. After my father died, my mother also let out her feet [to work in the fields]"; "because my father-in-law got sick and couldn't [do agricultural] work, the family needed a daughter-in-law who could work [in the fields]"; "big-footed [women] only marry those who want [brides who can do] heavy physical labor." ${ }^{19}$ Girls who had no work available that was both productive and compatible with bound feet (such as spinning) were either never bound or gained their families' acquiescence to unbind.

To provide a more focused test of the relationship between footbinding and hypergamy, we eliminated from the "bound" category women whose feet had been bound but then let out while still in their girlhood years. Often, the onset of a daughter's puberty signaled by her first menses prodded a mother into looking about for her future marital home. Footbound girls whose feet were already let out would not have been considered footbound by go-betweens or potential mothers-in-law. We thus focus on women from our sample whose feet were still bound at their age of marriage to evaluate whether footbinding was a pivotal factor enhancing marriage prospects, as so commonly assumed.

\section{Assessing Hypergamy}

Were women whose feet were bound at marriage better off in their marital households than they were in their natal households? To address this question, we looked at three factors that were important indicators of rural wealth in order to represent relative economic standing in our rural communities prior to collectivization: ownership of land, a house, and a draft animal (usually an ox).

\footnotetext{
${ }^{19}$ Jiangxi PZ ID \#2301133: “ 因为要让她种地、做事, 所以没给[她]包脚。父亲去世后, 母亲也放了脚”; Henan KF ID \#1901005: “因为公公生病不能干活, 家里需要能干活的媳妇”; Yunnan JC ID \#3103197: “大脚 Y头嫁人了要干重体力活.”
} 
These are retrospective data about facts such as land ownership, which are not necessarily remembered perfectly or about which interview subjects may wish to remain vague. Women often did not remember exactly how much land their natal families had while private ownership was still the norm. The quantity of land owned could be a sensitive topic, as it was related to class labels officially assigned during the Maoist period. ${ }^{20}$ It was a particularly sensitive topic in Sichuan at the time of data collection. Thus, for Sichuan, all we have is a statement of whether their family owned land with no information on how much was owned. For other regions, we did get some landholding information. A total of 1,129 women who responded about landholdings were able to give us a numeric estimate of land owned by their families. The average amount reported was about $13 \mathrm{mu}$ (亩), with a range (among those holding land) from 0.1 to 500 $m u$ (both these extremes were unusual). Accordingly, we evaluated whether women were better off at a very general level, by looking at whether their natal versus marital families owned any land, even a single draft animal, or owned any sort of house.

We find different results for Sichuan and the other regions. In our Northern, Central, and Southwestern sites, there is no evidence to suggest that women with bound feet were significantly better off in their marital households than they were in their natal ones (see table 3). In other words, despite the widespread belief that footbinding was to allow a girl to marry better, Northern, Central, and Southwestern footbound women did not consistently marry to a household that was wealthier by these indicators. By contrast, in Sichuan, footbound women were significantly more likely $(p<0.001)$ to have a marital family than a natal family with a house, land, and a draft animal.

In order to compare mobility of footbound women to not-bound women more directly, we asked: Were women with bound feet at marriage better off in their marital transitions than women whose feet were not bound at marriage (i.e., including both never-bound and unbound women)? Again, we looked at our wealth indicators separately and only at the presence or absence of ownership for each indicator.

Table 4 suggests that, in some places, women with bound feet fared better in their marital households than women whose feet were not bound at the time of marriage. Sichuan (as a region) shows marginally significant hypergamy on two of our three wealth indicators: owning a house $(p=0.03)$ and owning a draft animal $(p=0.04)$. The Southwestern region also shows significance for hypergamy but only on one indicator: owning a house $(p=0.02)$.

There were too few women whose feet were still bound at marriage (and for whom we have complete data regarding the other limiting conditions) to consider

\footnotetext{
${ }^{20}$ Occasional individuals volunteered their Maoist class labels, which were then noted, but Gates, Bossen, and Brown found it more prudent (for continuing the survey) not to directly ask for these labels.
} 
Table 3. Comparison of Ownership of House, Land, and Draft Animal Between Natal and Marital Households for Women Footbound at Marriage, Majority Cohorts

\begin{tabular}{|c|c|c|c|c|c|c|c|c|c|c|}
\hline \multirow[t]{2}{*}{ Region } & \multirow[t]{2}{*}{$\mathrm{n}$} & \multicolumn{2}{|c|}{ House } & \multirow[t]{2}{*}{$p$} & \multicolumn{2}{|c|}{ Land } & \multirow[t]{2}{*}{$p$} & \multicolumn{2}{|c|}{ Draft Animal } & \multirow[t]{2}{*}{$p$} \\
\hline & & $\overline{\text { Natal }}$ & Marital & & $\overline{\text { Natal }}$ & Marital & & Natal & Marital & \\
\hline Central & 10 & $88 \%$ & $89 \%$ & 0.93 & $75 \%$ & $67 \%$ & 0.73 & $67 \%$ & $78 \%$ & 0.60 \\
\hline North & 100 & $89 \%$ & $94 \%$ & 0.23 & $79 \%$ & $85 \%$ & 0.28 & $52 \%$ & $53 \%$ & 0.83 \\
\hline Sichuan & 994 & $59 \%$ & $67 \%$ & 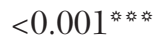 & $44 \%$ & $53 \%$ & 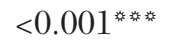 & $34 \%$ & $42 \%$ & 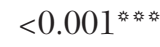 \\
\hline Southwest & 47 & $94 \%$ & $96 \%$ & 0.64 & $85 \%$ & $84 \%$ & 0.93 & $47 \%$ & $47 \%$ & $>0.99$ \\
\hline
\end{tabular}

For explanation of all tables, see the appendix. 
Table 4. Comparison of Marital Household Ownership of House, Land, and Draft Animal Between Women Footbound $(\mathrm{fb})$ and Not Bound $(\mathrm{nb})$ at the Time of Marriage, Majority Cohorts

\begin{tabular}{|c|c|c|c|c|c|c|c|c|c|c|c|}
\hline \multirow[t]{2}{*}{ Region } & \multicolumn{2}{|c|}{ Married Women } & \multicolumn{2}{|c|}{ House } & \multirow[t]{2}{*}{$p$} & \multicolumn{2}{|c|}{ Land } & \multirow[t]{2}{*}{$p$} & \multicolumn{2}{|c|}{ Draft Animal } & \multirow[t]{2}{*}{$p$} \\
\hline & $\mathrm{n}_{\text {total }}$ & $\mathrm{n}_{\text {minimum }}$ & $f b$ & $n b$ & & $f b$ & $n b$ & & $f b$ & $n b$ & \\
\hline Central & 41 & 6 & $89 \%$ & $92 \%$ & 0.76 & $66 \%$ & $86 \%$ & 0.29 & $78 \%$ & $49 \%$ & 0.11 \\
\hline North & 278 & 96 & $94 \%$ & $87 \%$ & 0.07 & $85 \%$ & $81 \%$ & 0.43 & $53 \%$ & $61 \%$ & 0.21 \\
\hline Sichuan & 3277 & 994 & $67 \%$ & $63 \%$ & $0.03^{\text {* }}$ & $53 \%$ & $49 \%$ & 0.053 & $42 \%$ & $38 \%$ & $0.04^{*}$ \\
\hline Southwest & 157 & 45 & $96 \%$ & $84 \%$ & 0.02 * & $84 \%$ & $72 \%$ & 0.10 & $47 \%$ & $47 \%$ & 0.96 \\
\hline \multicolumn{12}{|l|}{ Sichuan Counties } \\
\hline Ba Xian (BX) & 229 & 88 & $78 \%$ & $58 \%$ & $0.001^{\text {* * }}$ & $60 \%$ & $48 \%$ & 0.06 & $80 \%$ & $55 \%$ & 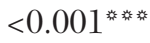 \\
\hline Dazhu (DZ) & 354 & 116 & $56 \%$ & $49 \%$ & 0.22 & $47 \%$ & $41 \%$ & 0.34 & $46 \%$ & $45 \%$ & 0.90 \\
\hline Emei (EM) & 487 & 91 & $82 \%$ & $82 \%$ & 0.99 & $64 \%$ & $64 \%$ & 0.94 & $52 \%$ & $58 \%$ & 0.31 \\
\hline Jiajiang (JJ) & 210 & 29 & $86 \%$ & $84 \%$ & 0.76 & $76 \%$ & $76 \%$ & 0.96 & $54 \%$ & $42 \%$ & 0.33 \\
\hline Longquan (LQ) & 485 & 186 & $65 \%$ & $58 \%$ & 0.10 & $47 \%$ & $36 \%$ & $0.02^{* *}$ & $34 \%$ & $26 \%$ & $0.04^{*}$ \\
\hline Lezhi (LZ) & 470 & 136 & $68 \%$ & $65 \%$ & 0.58 & $54 \%$ & $61 \%$ & 0.14 & $49 \%$ & $34 \%$ & 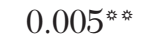 \\
\hline Mingshan (MS) & 61 & 8 & $61 \%$ & $100 \%$ & 0.18 & $88 \%$ & $72 \%$ & 0.31 & $38 \%$ & $49 \%$ & 0.54 \\
\hline Nanchong (NC) & 366 & 94 & $63 \%$ & $54 \%$ & 0.16 & $39 \%$ & $32 \%$ & 0.20 & $41 \%$ & $32 \%$ & 0.08 \\
\hline Suining (SN) & 374 & 154 & $62 \%$ & $55 \%$ & 0.13 & $56 \%$ & $41 \%$ & $0.006^{\text {*** }}$ & $26 \%$ & $26 \%$ & 0.99 \\
\hline Zigong (ZG) & 241 & 92 & $58 \%$ & $34 \%$ & 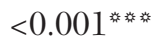 & $55 \%$ & $31 \%$ & 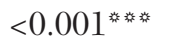 & $25 \%$ & $19 \%$ & 0.31 \\
\hline
\end{tabular}


quantitative analysis of hypergamy at the level of individual sites for most regions. In Sichuan, however, we find local-level variation (see table 4). Half of these sites (DZ, EM, JJ, MS, NC) show no evidence that footbound women were more likely to marry up than not-bound women on any of the wealth indicators we use. Two sites (LZ, SN) show significance for a single wealth indicator. Three sites (BX, LQ, ZG) show significance for two indicators. The important point here is that, although there was no pattern of hypergamy for most footbound women on most of our wealth indicators, conditions could yield local patterns of hypergamy for footbound women.

For reasons discussed briefly below and in more detail elsewhere (Bossen 2002, 2008; Bossen et al. 2011; Gates 1989, 2001, 2005, forthcoming), we expect footbinding to be linked to female handcraft labor. Interestingly, all three sites with significant evidence of hypergamy on two indicators were on the outskirts of thriving urban areas: Longquan was near Chengdu, the provincial capital; Ba Xian was a dependent hinterland of Chongqing, Sichuan's emerging commercial capital; and the Zigong site was near the commercially active city of Zigong. Cities created demand for girls' services and products. Zigong, for example, is described by Madeleine Zelin $(2005,290)$ as having been an extraordinary nexus of Chinese traditional industry based on salt, forest products, and tong oil. Moreover, the capital for development of these industries came in part from local involvement in the cotton trade (Zelin 2005 76, 81, 99), which would have created continuing demand for female labor. The two sites with hypergamy on a single indicator-Lezhi and Suining-had early and lasting connections with cotton textile production, again, requiring much female handcraft labor. Explanation of why, in these specific places, girls' handcraft labor and footbinding were linked to hypergamy must await further analysis of the Sichuan data (Gates, forthcoming).

Tables 3 and 4 examine each wealth indicator (house, land, and draft animal) independently. Given that land was much more important to the well-being of rural Chinese than a house or a draft animal, however, we considered whether combining these separate measures into a single marital mobility index (MMI) that emphasizes land would yield a more general pattern of hypergamy. We calculated MMI by creating a wealth index for each household (marital and natal). A positive MMI indicates upward mobility.

This index weights each of the wealth factors as follows: land $=2$, house $=1$, and draft animal $=1$. We debated whether to give house and draft animal equal weight in the index, or whether to weight draft animal more (land $=2.5$, house $=1$, draft animal =1.5). A draft animal would have allowed a poor family to find work as farm laborers, regardless of whether they had a house. On the other hand, a house allowed work and storage space for looms, spinning wheels, and small-scale businesses, such as manufacturing sugar (e.g., from rice) or bricks. A test on the Sichuan data demonstrated that significance values were insensitive to these different weighting schemes. We therefore arbitrarily chose the first index, where house and draft animal are assigned equal value. 
Table 5. Comparison of Women's Marital Mobility Across Sites, Majority Cohorts Only

\begin{tabular}{lccccc}
\hline & Central & North & Sichuan & Southwest & All Sites \\
\hline \# All Women & 44 & 287 & 3327 & 153 & 3811 \\
Upward Mobility (MMI > 0) & $29.5 \%$ & $27.5 \%$ & $31.5 \%$ & $31.4 \%$ & $31.1 \%$ \\
No Mobility (MMI = 0) & $45.5 \%$ & $49.4 \%$ & $46.9 \%$ & $34.0 \%$ & $46.5 \%$ \\
Downward Mobility (MMI < 0) & $25.0 \%$ & $23.0 \%$ & $21.6 \%$ & $34.6 \%$ & $22.3 \%$ \\
\hline \# Women Still Bound at & 6 & 94 & 994 & 45 & 1139 \\
$\quad$ Marriage & & & & & \\
Upward Mobility (MMI > 0) & $16.7 \%$ & $27.7 \%$ & $34.4 \%$ & $28.9 \%$ & $33.5 \%$ \\
No Mobility (MMI = 0) & $50.0 \%$ & $44.7 \%$ & $46.1 \%$ & $35.6 \%$ & $45.6 \%$ \\
Downward Mobility (MMI < 0) & $33.3 \%$ & $27.7 \%$ & $19.5 \%$ & $35.6 \%$ & $20.9 \%$ \\
\hline \# Women Not Bound at & 30 & 167 & 2281 & 97 & 2575 \\
$\quad$ Marriage & & & & & \\
$\quad \begin{array}{l}\text { Upward Mobility (MMI > 0) } \\
\text { No Mobility (MMI = 0) }\end{array}$ & $33.3 \%$ & $28.7 \%$ & $30.2 \%$ & $33.0 \%$ & $30.3 \%$ \\
Downward Mobility (MMI < 0) & $23.3 \%$ & $49.7 \%$ & $47.1 \%$ & $30.9 \%$ & $46.7 \%$ \\
& & $21.6 \%$ & $22.6 \%$ & $36.1 \%$ & $23.0 \%$
\end{tabular}

For explanation of all tables, see the appendix.

Table 5 shows marital mobility for women in majority cohorts across regions in terms of our weighted index (MMI), and table 6 shows the results of significance tests on the difference between the mean MMIs. The figures in table 5 show relatively little marital mobility at all, and less hypergamy. Only about 31

Table 6. Significance Results of Mean MMI Differences

\begin{tabular}{lccc}
\hline Region & \# of Women & Mean MMI & $p$ \\
\hline $\begin{array}{l}\text { Central } \\
\text { Bound at marriage }\end{array}$ & 6 & -0.33 & 0.37 \\
$\begin{array}{l}\text { Not bound at marriage } \\
\text { North }\end{array}$ & 30 & +0.27 & \\
$\begin{array}{l}\text { Bound at marriage } \\
\text { Not bound at marriage }\end{array}$ & 94 & +0.13 & 0.64 \\
Sichuan & 167 & +0.12 & \\
$\begin{array}{l}\text { Bound at marriage } \\
\text { Not bound at marriage }\end{array}$ & & & $0.007^{\text {**** }}$ \\
Southwest & 994 & +0.35 & \\
$\begin{array}{l}\text { Bound at marriage } \\
\text { Not bound at marriage }\end{array}$ & 2281 & +0.17 & \\
& & & 0.68 \\
\hline
\end{tabular}

For explanation of all tables, see the appendix. 
percent of women marry up, across regions; just under half of all women surveyed married to a household at the same wealth level as their natal household. The cultural belief that "marriage should be between equals" is supported by our evidence, though with the caveat that there was not inconsiderable downward mobility: about 22 percent of women married down.

Table 6 indicates that the difference in average MMI between women bound and not bound at marriage is significant only in Sichuan. In other words, using this index, women living in our Northern, Central, and Southwestern samples married on average to a household at or near the level of wealth of their natal household-regardless of whether they were bound at marriage or not. Moreover, downward mobility was only slightly less frequent than upward mobility. These results support the matching-doors ideal and counter the expectation of many that rural Chinese women married to wealthier households. In Sichuan, by contrast, hypergamy was correlated with footbinding.

Table 6, however, provided some other surprising results. The mean MMI for women still bound at marriage in both the Central and Southwestern regions was actually negative. Although there is no significance to the difference between the averages for footbound and not-bound women in these regions, these numbers raise questions about the possible downward mobility of footbound women in some areas.

We therefore conducted a further test on the dependence between marital mobility and footbinding status (see table 7). This test asks whether the proportions of women who have upward, downward, or no mobility are dependent on footbinding status. (Again we ran the test for majority cohorts of women who married prior to 1950.) Here, we see no evidence that marital mobility was dependent on footbinding for the Central, Northern, or Southwestern samples.

These results confirm the findings in previous tables except on one point: In table 4, we found footbound women in the Southwest slightly more likely to have a marital family with a house than not-bound women. How do we interpret this contrasting result? According to table 4, 8 percent more women bound at marriage had marital households with houses than not-bound women. That 8 percent difference is statistically significant, but is it important or meaningful? There is no definitive answer to this question, but the difference is slight and disappears when we consider a broader measure of wealth (MMI, combining all three indicators) in tables 6 and 7. Taken together, these results suggest that in the Southwest sample, footbinding was not a reliable means to upward mobility. For Sichuan, we see evidence in table 7 that a disproportionate number of women married up because they were bound at marriage age. Thus, across all the tables for Sichuan, we see a correlation between footbinding and marital mobility.

Could the consistent correlation in Sichuan be due to a historical period effect? The first half of the twentieth century was one of enormous upheaval in China, including years of war with Japan (1937-45) and civil war (1945-49), which affected the livelihoods of many rural households, including in areas where we 
interviewed. We examined whether women born earlier in the century had different marital mobility outcomes based on footbinding, since these women's marriages were more likely to have occurred before the war years (see table 8). Such a period effect would skew our results, since women born early in the twentieth century are underrepresented in our sample outside of Sichuan (many women had died or become infirm by the time of our interviews).

We tested for period effects in each of our regions by examining whether dependence of marital mobility on footbinding status varied by the historical period in which marriage occurred (see table 8). Due to concern about whether war removed a correlation that previously existed, we divided our sample of women (from majority birth cohorts) into three historical periods based on the year of their marriage: 1907-24, 1925-36, and 1937-49 (war years). (We selected 1925 as the date to divide our earliest cohorts because it is the earliest marriage year in our samples for regions outside Sichuan.) For the Central, Northern, Southwestern regions, we have data from women who married in the latter two periods. In these samples, there is no evidence of a period effect. In other words, the proportion of women in each mobility class (upward, downward, or neutral) was not significantly affected by the time period. (Even examined in terms of binding status, these regions showed no evidence of period effect; data not shown.)

Sichuan was once again exceptional: there was a significant historical effect. For women married earliest (1907-24), regardless of binding status, fewer women were downwardly mobile than in later cohorts. When examined in terms of binding status, it was only Sichuanese women not bound at marriage who showed this period effect. In other words, upward mobility was dependent upon being bound at marriage across all historical periods in Sichuan (see table 7), but in the earliest period, fewer women not bound at marriage were downwardly mobile than expected (see table 8). Notably, most Sichuanese women who married in this earliest time period were still bound at marriage. For Sichuanese women who married later, most women were not bound at marriage. (In other regions, our sample sizes for women married before the war years are too small to reliably assess these proportions).

The effects of historical period on our overall results thus appear minimal. Sichuan's period effect showed less downward mobility among women married before 1924. However, the correlation between being footbound at marriage and upward mobility obtained across historical periods in Sichuan. Moreover, there is no evidence of any period effect outside Sichuan. Thus, with the caveat that there are no data on women outside Sichuan married before 1925, we can be reasonably confident in our results from women married later (1925-49) regarding the relationship between footbinding and marital mobility.

The marriages of women in our Northern, Central, and Southwestern sites do not show a general pattern of footbinding leading to hypergamy. The Southwestern sample showed footbinding helped hypergamy on one wealth indicator 
Table 8. Historical Period Effects on Marital Mobility

Women in majority (birth) cohorts who married before 1950.

\begin{tabular}{|c|c|c|c|c|c|}
\hline \multirow[t]{2}{*}{ Period in Which Married } & \multirow[t]{2}{*}{$\mathrm{n}$} & \multicolumn{3}{|c|}{ Marital Mobility } & \multirow[t]{2}{*}{$p$ Overall } \\
\hline & & Upward $(M M I>0)$ & No Mobility $(M M I=0)$ & Downward $(M M I<0)$ & \\
\hline $\begin{array}{l}\text { Central (All Women) } \\
\text { 1925-36 } \\
1937-49\end{array}$ & $\begin{array}{r}5 \\
38\end{array}$ & $\begin{array}{l}40 \% \\
29 \%\end{array}$ & $\begin{array}{l}40 \% \\
45 \%\end{array}$ & $\begin{array}{l}20 \% \\
26 \%\end{array}$ & 0.88 \\
\hline $\begin{array}{l}\text { North (All Women) } \\
1925-36 \\
1937-49\end{array}$ & $\begin{array}{r}29 \\
245\end{array}$ & $\begin{array}{l}34 \% \\
27 \%\end{array}$ & $\begin{array}{l}59 \% \\
49 \%\end{array}$ & $\begin{array}{r}7 \% \\
24 \%\end{array}$ & 0.06 \\
\hline $\begin{array}{l}\text { Sichuan (All Women) } \\
1907-24 \\
1925-36 \\
1937-49\end{array}$ & $\begin{array}{r}281 \\
1620 \\
1424\end{array}$ & $\begin{array}{l}36 \% \\
32 \% \\
30 \%\end{array}$ & $\begin{array}{l}48 \% \\
47 \% \\
46 \%\end{array}$ & $\begin{array}{l}15 \%(-)^{* * *} \\
21 \% \\
23 \%(+)^{\bullet}\end{array}$ & $0.03^{*}$ \\
\hline $\begin{array}{l}\text { Southwest (All Women) } \\
1925-36 \\
1937-49\end{array}$ & $\begin{array}{r}8 \\
145\end{array}$ & $\begin{array}{l}25 \% \\
32 \%\end{array}$ & $\begin{array}{l}13 \% \\
35 \%\end{array}$ & $\begin{array}{l}63 \% \\
33 \%\end{array}$ & 0.21 \\
\hline $\begin{array}{l}\text { Sichuan: Women Bound } \\
\text { 1907-24 } \\
1925-36 \\
1937-49\end{array}$ & $\begin{array}{l}\text { arriage } \\
196 \\
591 \\
207\end{array}$ & $\begin{array}{l}40 \% \\
32 \% \\
35 \%\end{array}$ & $\begin{array}{l}43 \% \\
48 \% \\
44 \%\end{array}$ & $\begin{array}{l}17 \% \\
20 \% \\
21 \%\end{array}$ & 0.34 \\
\hline $\begin{array}{l}\text { Sichuan: Women Not BC } \\
1907-24 \\
1925-36 \\
1937-49\end{array}$ & $\begin{array}{l}\text { Marr } \\
77 \\
1002 \\
1200\end{array}$ & $\begin{array}{l}29 \% \\
31 \% \\
30 \%\end{array}$ & $\begin{array}{c}62 \%(+)^{*} \\
47 \% \\
46 \%\end{array}$ & $\begin{array}{l}9 \%(-)^{* * * *} \\
22 \% \\
24 \%\end{array}$ & $0.011^{*}$ \\
\hline
\end{tabular}

3
0
0
0
0
0
0
0
0
0
0
0
0
0

For explanation of all tables, see the appendix. 
(house, in table 4), but that effect disappeared when considering three indicators taken together (MMI, in tables 6 and 7). In Sichuan, however, there are correlations between footbinding and hypergamy (see tables 3, 4, 6, and 7), even though the majority of women married at or below the wealth level of their natal family (see table 5). These quantitative assessments of women's actual marital mobility suggest that the cultural belief that "footbinding leads to hypergamy" does not reflect most marital outcomes.

\section{Implications About Hypergamy and Social Causation}

These analyses suggest that some major assumptions about the lives of pre-1949 rural Chinese may be mistaken. Our evidence suggests that there was some upward mobility for rural Chinese women in the first half of the twentieth century: about 31 percent of all women (for whom we could calculate our marital mobility index) married up (see table 5). Our findings also suggest that the cultural belief_-often transmitted from mothers to their daughters as they were binding their feet-that footbinding would improve girls' marital prospects was not generally true, except in Sichuan where the upward rise of footbound women did show an interdependence between footbinding and hypergamy. Nevertheless, more girls everywhere-including Sichuan-married to families at the same economic level as their natal households than married up, and it was not terribly uncommon for girls to marry down (see table 5).

Our evidence raises methodological and theoretical questions about social causation. How do we identify people's "real" motivations? About one-third of women believed their feet were bound so that they would marry at all, yet this belief was clearly not true. Those individuals and folk sayings suggesting that footbinding would lead to a better marriage were accurate only in Sichuan, even though the sayings and reports were much more widely spread. This discovery, however, required extensive quantitative data. We suggest that collaborative and comparative approaches that gather quantitative data allow us to evaluate the relative accuracy of widely accepted beliefs about customs as well as to document diversity and change.

Evaluating social causation is more complicated. Even if we privilege beliefs to the point where we say that mothers bound their daughters' feet because they believed it would lead to better marriages, we must still confront the question of why the cultural belief persisted down the generations in spite of the reality that most footbound girls did not make better marriages. How salient were stories of girls who married up or down? Do people, on average, recall more instances of upward mobility, even if it was not the norm? Perhaps the mobility of Sichuanese women still bound at marriage captured people's imagination and made a memorable story to pass along. Still, these women were not Cinderella marrying a prince. Our data come from rural women whose hypergamy meant going to a 
marital home that owned land and a house and maybe also a draft animal, instead of a marital home with only one of these wealth indicators.

We must also confront the question of why footbinding ended, despite the continuation of the cultural belief in its association with marriage. Girls were not passive recipients of the painful binding process, as the case of Ms. Xu illustrates. Many mothers repeatedly rebound daughters who removed or loosened their bindings. Such persistence by mothers could, in principle, be related to cultural belief, but if cultural belief explains their persistence then what explains why mothers suddenly gave up binding and rebinding daughters' feet? Evidence suggests that the cultural belief persisted: Many women who unbound reported their mother's disapprobation and their admonition that unless she rebound a girl would likely never marry.

We deal elsewhere (Bossen et al. 2011; Gates 1989, 2001, forthcoming) with the question of why footbinding ended, which can be summarized by saying that we have growing evidence that footbinding was a form of labor control to boost the contribution of young girls to handcraft production (cf. Blake 1994, 698707). The case of Ms. Wang illustrates the point. When her family lost its weaver, she was bound at a younger age than her sister had been and put to work immediately spinning and weaving to help support the family. Her elder sister, less competent at these tasks, was married off at the traditional age, while Wang herself was kept working for her natal household for several more years to the detriment of her marital welfare. Wang's footbinding functioned, and may have been intended, to boost her labor contributions to the family. While we cannot know how productive Wang might have been with natural feet, we do know that she was among the most productive of the spinners and weavers interviewed. We also know that neither her bound feet nor her huge economic contribution to her natal family garnered her a better marriage. It is not unreasonable, either theoretically (Brown and Feldman 2009; Lipatov, Brown, and Feldman 2011) or empirically (Brown 2008), to suggest that economic factors can lead people to act in ways that disagree with some of their beliefs.

If, for the purposes of considering social causation, we grant the argument that footbinding constituted a form of labor control, how do we assess what "caused" families to bind their daughters' feet? The labor control claim suggests an economic motivation, but many daughters believed they were being bound to their own benefit: to marry at all, or to marry well. It is possible, of course, that mothers did not themselves believe that footbinding led to a better marriage, that these were only words meant to ease the painful binding process that was intended as a form of labor control. Since we have only been able to interview women who were bound, and not the mothers and others who bound them (because they are long dead), we cannot be certain about the binders' intentions. However, the fact that some mothers continued to admonish daughters they should be footbound even when spinning and other handcraft production for sale was no longer an option suggests that these mothers did believe that 
footbinding was crucial for marriage. If those who made the decision about binding daughters' feet believed and intended it as a means for their daughters' marital prospects, how do we reconcile the frequent falsity of the belief (in achieving its intended result) with the persistence of the custom for so long, and how do we reconcile the continuation of the belief with the termination of the custom, in our understanding of footbinding's social causation? We think changes in the larger political economy that threw spinners and other handcraft producers out of work explain the cause of footbinding's demise (Blake 1994; Bossen 2011; Bossen et al. 2011; Gates 1989, 2001, forthcoming).

If so, then are people's mistaken beliefs that footbinding improved marital prospects causally relevant to the persistence of footbinding in previous generations? Fred Blake (1994, 694-95) argues for the importance of neo-Confucian doctrine in the complex of factors that caused footbinding (cf. Gates 1989). Although Blake $(1994,698-707)$ privileges the economic explanation, he argues that neo-Confucian beliefs were crucial to the persistence of footbinding because they obfuscated not merely the material basis of the custom but more importantly the material contributions of Chinese women. Social theorist Ernest Gellner (1959, 494), however, suggested that where belief does not conform to social reality, causation cannot be assumed. In agreement with Gellner, the evidence presented here strongly suggests that in future considerations of social causation, we must be careful not to assume that people's stated beliefs are a sufficient or even necessarily a relevant explanation of social causation. In any given empirical case, the causation of beliefs will need to be demonstrated.

Patricia Ebrey $(1991,5)$ noted that the "relative incidence of hypergamous marriages has never been adequately studied." This observation is particularly true for rural Chinese women of poor to moderate economic status, for these women have left few written or spoken records to represent them. For the most part, scholars have generalized about them based on relatively few anecdotes and texts, mostly drawn from urban and/or elite sources. Here, we have endeavored to identify and understand some of the social realities they experienced with regard to footbinding and marriage. We did so by examining some of the untested explanations that have been put forth, testing them against empirical evidence collected from a large sample of rural women across China who lived during the early twentieth century. By recognizing the experiences of large segments of the population who live outside urban and elite circles, we can better understand the dynamics of pervasive gender inequalities in China.

\section{Acknowledgments}

The data from the Northern, Central, and Southwestern regions are part of a research project run by Melissa J. Brown, funded by the U.S. National Science 
Foundation (\#BCS-0613297, \#BCS-1238999). This project was also supported by the Radcliffe Institute for Advanced Study at Harvard University and Stanford University's Center for East Asian Studies. The data from Sichuan are part of a research project run by Hill Gates, funded by the Harry Frank Guggenheim Program on Violence and Aggression against Women. We thank our many research collaborators and assistants in China and North America as well as the thousands of rural Chinese women who shared information about their lives with us.

\section{List of References}

Appiah, Kwame Anthony. 2010. The Honor Code: How Moral Revolutions Happen. New York: W.W. Norton \& Company.

Blake, C. Fred. 1994. "Footbinding in Neo-Confucian China and the Appropriation of Female Labor." Signs 19(3):676-712.

Bossen, Laurel. 2002. Chinese Women and Rural Development: Sixty Years of Change in Lu Village, Yunnan. Lanham, Md.: Rowman \& Littlefield.

2007. "Village to Distant Village: The Opportunities and Risks of Long-Distance Marriage Migration in Rural China." Journal of Contemporary China 16(50):97-116. . 2008. "Hand und Fuß gebunden: Frauenarbeit und das Binden der Füße im China des frühen 20. Jahrhunderts." [Bound hand and foot: Women's work and footbinding in early twentieth century China]. Translated by Mareile Flitsch. Technikgeschichte [History of technology] 75:117-40.

— 2011. "Women's Labor and Footbinding in Early $20^{\text {th }}$ Century Rural China." Paper presented at the Annual Conference of the Association for Asian Studies, Honolulu, Hawai'i, April 1.

Bossen, Laurel, Wang Xurui, Melissa Brown, and Hill Gates. 2011. "Feet and Fabrication: Footbinding and Early 20th Century Rural Women's Labor in Shaanxi." Modern China 37(4):347-83. doi:10.1177/0097700411403265.

Brown, Melissa J. 2004. Is Taiwan Chinese? The Impact of Culture, Power, and Migration on Changing Identities. Berkeley: University of California Press.

2007. "Ethnic Identity, Cultural Variation and Processes of Change: Rethinking the Insights of Standardization and Orthopraxy." Special issue, Modern China 33(1):91124. doi:10.1177/0097700406294701.

— 2008. "When Culture Does Not Affect Behavior: The Structural Basis of Ethnic Identity." In Explaining Culture Scientifically, ed. Melissa J. Brown162-83. Seattle: University of Washington Press.

_ 2010. "Changing Authentic Identities: Evidence from Taiwan and China." Journal of the Royal Anthropological Institute 16:459-79. doi:10.1111/ j.1467-9655.2010.01634.x.

Brown, Melissa J., and Marcus W. Feldman. 2009. "Sociocultural Epistasis and Cultural Exaptation in Footbinding, Marriage Form, and Religious Practices in Early 20th-Century Taiwan." Proceedings of the National Academy of Sciences USA 106 (52):22139-44. doi:10.1073_pnas.0907520106.

Buck, John Lossing. 1937. Land Utilization in China, 3 vols. Nanking: University of Nanking.

Cohen, Mrron. 1976. House United, House Divided: The Chinese Family in Taiwan. New York: Columbia University Press. 
2005. Kinship, Contract, Community, and State: Anthropological Perspectives on China. Stanford, Calif.: Stanford University Press.

Davis, John F. 1836. A General Description of the Empire of China, 2 vols. New York: Harper \& Brothers.

Ebrey, Patricia Buckley. 1991. "Introduction." In Marriage and Inequality in Chinese Society, eds. Rubie S. Watson and Patricia Buckley Ebrey, 1-24. Berkeley: University of California Press.

Eyferth, Јасов. 2009. Eating Rice from Bamboo Roots: The Social History of a Community of Handicraft Papermakers, 1920-2000. Cambridge, Mass.: Harvard University Asia Center, Harvard East Asia Monograph.

Fielde, Adele M. 1887. Pagoda Shadows. London: T. Ogilive Smith.

GaO HongXIng (高洪兴). 1995. Chanzu shi [缠足史 Footbinding: A journey through time]. Shanghai: Wenyi chuban she.

Gates, Hill. 1989. “The Commoditization of Chinese Women.” Signs 14(4):799-832.

—. 1993. "Cultural Support for Birth Limitation Among Urban Capital-Owning Women." In Chinese Families in the Post-Mao Era, eds. Deborah Davis and Stevan Harrell, 251-74. Berkeley: University of California Press.

—. 1996. China's Motor: A Thousand Years of Petty Capitalism. Ithaca, N.Y.: Cornell University Press.

—. 2001. "Footloose in Fujian: Economic Correlates of Footbinding." Comparative Studies in Society and History 43(1):130-48.

—. 2005. "Girls' Work in China and Northwestern Europe: Of Guniang and Meisjes." In Marriage and the Family in Eurasia: Perspectives on the Hajnal Hypothesis, eds. Theo Engelen and Arthur P. Wolf, 319-42. Amsterdam: Aksant.

— 2008. "Bound Feet: How Sexy Were They?" The History of the Family 13:58-70.

- Forthcoming. Hand and Foot: Footbinding and Girls' Labor in Sichuan. Oxford and New York: Routledge.

Gellner, Ernest. 1959. "Holism Versus Individualism in History and Sociology." In Theories of History, ed. Patrick Gardner, 488-503. New York: The Free Press.

Greenhalgh, Susan. 1977. "Bound Feet, Hobbled Lives: Women in Old China." Frontiers: A Journal of Women Studies 2(1):7-21.

Hershatter, Gail. 1991. "Prostitution and the Market in Women in Early TwentiethCentury Shanghai." In Marriage and Inequality in Chinese Society, eds. Rubie S. Watson and Patricia Buckley Ebrey, 256-85. Berkeley: University of California Press.

2011. The Gender of Memory: Rural Women and China's Collective Past. Berkeley: University of California Press.

JaCKa, TAmara. 1996. Women's Work in Rural China: Change and Continuity in an Era of Reform. Cambridge: Cambridge University Press.

Jackson, Beverly. 1997. Splendid Slippers: A Thousand Years of an Erotic Tradition. Berkeley, Calif.: Ten Speed Press.

Jaschor, Maria. 1988. Concubines and Bond Servants: The History of a Chinese Custom. London: Zed Books.

Judd, Ellen. 1989. "Niangjia: Chinese Women and Their Natal Families." Journal of Asian Studies 48(3):525-44.

KE JishENG (柯基生). 1995. San cun jinlian [三寸金莲The three-inch golden lotus]. Yonghe, Taiwan: Chanye jingbao zazhi she.

Ko, Dorothy. 2005. Cinderella’s Sisters: A Revisionist History of Footbinding. Berkeley: University of California Press. 
Levy, Howard S. 1967. Chinese Footbinding: The History of a Curious Erotic Custom. New York: Bell Publishing Company.

Lipatov, Mikhail, Melissa J. Brown, and Marcus W. Feldman. 2011. "The Influence of Social Niche on Cultural Niche Construction: Modelling Changes in Belief About Marriage Form in Taiwan." Special issue, Philosophical Transactions of the Royal Society, B 366:889-900. doi:10.1098/rstb.2010.0247.

MacGowan, John. 1913. How England Saved China. London: T. Fisher Unwin.

Mackie, Gerry. 1996. "Ending Footbinding and Infibulation: A Convention Account." American Sociological Review 61(6):999-1017.

Mann, Susan. 1997. Precious Records: Women in China's Long Eighteenth Century. Stanford, Calif.: Stanford University Press.

McLaren, Anne E. 1998. "Crossing Gender Boundaries in China: Nüshu Narratives." Intersections 1:1-16. http://intersections.anu.edu.au/issue1/nushu2.html (accessed April 30, 2012).

- 2008. Performing Grief: Bridal Laments in Rural China. Honolulu: University of Hawai i Press.

Mueggler, Erik. 2001. The Age of Wild Ghosts: Memory, Violence, and Place in Southwest China. Stanford, Calif.: Stanford University Press.

Pruitt, Ida. [1945] 1967. A Daughter of Han. Stanford, Calif.: Stanford University Press. See, Lisa. 2006. Snow Flower and the Secret Fan. New York: Random House.

Sommer, Matthew H. 2000. Sex, Law, and Society in Late Imperial China. Stanford, Calif.: Stanford University Press.

Stockard, Janice. 1992. Daughters of the Canton Delta: Marriage Patterns and Economic Strategies in South China, 1860-1930. Stanford, Calif.: Stanford University Press.

Telford, Ted A. 1992. “Covariates of Men’s Age at First Marriage: The Historical Demography of Chinese Lineages." Population Studies: A Journal of Demography 46(1):19-35. doi:10.1080/0032472031000145986.

Wang PInG, 2000. Aching for Beauty: Footbinding in China. Minneapolis: University of Minnesota Press.

Watson, Rubie S. 1991. "Wives, Concubines, and Maids." In Marriage and Inequality in Chinese Society, eds. S. Watson and Patricia Buckley Ebrey, 231-55. Berkeley: University of California Press.

Wolf, Arthur P., and Huang Chieh-shan. 1980. Marriage and Adoption in China, 18451945. Stanford, Calif.: Stanford University Press.

YAO LingXI (姚靈犀). 1936. Caifeilu xubian [采菲錄:續編 Picking radishes], 2 vols. Tianjin: Shidai Gongsi.

Zelin, Madeleine. 2005. The Merchants of Zigong. New York: Columbia University Press.

\section{ApPENDix: Explanation of TABLES}

Table 1 includes all women, regardless of marriage date. Multiple answers were possible, as were other answers not presented, so percentages do not sum to 100 . The most common responses are shown.

Table 2 includes all women marrying before 1950 (not just women from majority cohorts). Sums of Ever- and Never-Bound fall short of $n$ due to missing data (from Central: 2; North: 4; Sichuan: 0; Southwest: 5); percentages 
do not include missing data. "Bound at Marriage" and "Unbound Before Marriage" include only ever-bound women whose unbinding status, unbinding age, and age at marriage were known ( $n=$ Central: 72 ; North: 230; Sichuan: 2,491 ; Southwest: 123). "Unbound" includes only ever-bound women whose unbinding status was known ( $n=$ Central: 92; North: 283; Sichuan: 3,253; Southwest: 136). "Bound After Marriage" includes only ever-bound women whose age at binding and age at marriage were known ( $n=$ Central: 212; North: 396; Sichuan: 4,869; Southwest: 190).

For tables $\mathbf{3}, \mathbf{4}, \mathbf{7}$, and $\mathbf{8}$, we used a log-likelihood $(\mathrm{G})$ test to determine statistical significance for all hypotheses. This test deals well with non-continuous data and does not assume normal distribution. A $p$ value of 0.05 (or below) means that the results could happen by chance owing to sampling error only 5 percent of the time (or less). Percentages are rounded to the nearest integer value, and $p$ values are generally given to two decimal places, but to three decimal places if the precision of significance is unclear (e.g., $0.007^{\text {* and }}$ 0.014 * both round to 0.01 ).

In table 3, Central data for natal house $=8$; marital land $=6$; marital draft animal $=9$. Northern data for marital house $=105$; marital land $=106$; marital draft animal $=107$. Sichuan data for marital house $=1,024$; marital land $=$ 1,025; marital draft animal = 1,024. Southwestern data for marital land $=45$.

In table 4, numbers are given for both the total number of women and the smallest subset (i.e., the minimum $n$ between bound or not bound at marriage), because the significance of the $\mathrm{G}$ test is dependent on both. The $n_{\text {total }}$ represents data for which we have all the necessary information.

In table 5, percentages exclude individuals with missing data and normalize over the known data (for women whose MMI we could calculate). Total $n$ may vary from numbers presented elsewhere due to missing data.

Table 6 includes only women for whom MMI could be calculated. Because MMIs are not normally distributed, a non-parametric (Wilcoxon's Rank Sum) test was used to determine differences in the means.

In table 7, percentages sum by row. For Sichuan, a log-likelihood test indicated that overall proportions diverged from expected values (i.e., under the null hypothesis that MMI and footbinding are independent). Deviations of individual cells from expected values were determined using a log-likelihood goodness-of-fit test, where expected proportions were taken to be the product of the marginals. The cell marked $(+)$ alone was significantly higher than expected under the null hypotheses $(p=0.047)$.

Table 8 includes women of majority birth cohorts who married before 1950 . In the section "Sichuan (All Women), " for just the (-) cell, $p=0.01^{*}$; for just the $(+)$ cell, $p=0.07$. In the section "Sichuan: Women Not Bound at Marriage," for just the $(-)$ cell, $p=0.004^{*}$; for just the $(+)$ cell, $p=0.04$. Deviations of individual cell values determined as in table 7 . 